\title{
ESP Course Book Evaluation from the Perspectives of Teachers, Cadets, and Graduates: The Case of Maritime English
}

\author{
Latifa Ika Sari \\ Politeknik Ilmu Pelayaran Semarang \\ Semarang, Indonesia \\ latifa.ika@gmail.com
}

\author{
Ria Hermina Sari \\ Politeknik Ilmu Pelayaran Semarang \\ Semarang, Indonesia \\ ria.hermina.sari@gmail.com
}

\begin{abstract}
Course books are considered as important elements in the language teaching and learning process. This study was aimed to evaluate a course book used in Preparation Class of Maritime English Test in one of Merchant Marine Polytechnic from three perspectives: teachers, graduates, and cadets. This study employed a qualitative descriptive analysis. There were 12 teachers, 111 cadets and 14 graduates involved in this study to give their opinions. Textbook evaluation checklist developed by Daoud and Celce-Murcia (1979) was adopted with several adjustments and used as a guide in collecting data. There were five aspects of the book to be analyzed: subject matter, vocabulary and structure, exercise, illustration, and physical make-up. The data were recapitulated, analyzed, and described qualitatively. The findings revealed that the book covers various materials, including maritime vocabulary and grammar, but they are not organized systematically. The exercises are sufficient, but some parts need more addition. The illustration and the physical make-up need to be improved to enhance the process of language teaching and learning. It is concluded that the coursebook investigated in this study needs several revisions and improvement.
\end{abstract}

Keywords: coursebook, evaluation, Maritime English

\section{INTRODUCTION}

\section{A. Background}

Maritime English (ME) is the international working language in the maritime industry. It is a language used at sea for communication among crew members. On the ship, all manuals, publications, and instructions are written in English. In vessels with a multinational crew, Maritime English becomes the only means of communication to achieve safety and security of voyages. In this context, Maritime English is said as lingua franca, a language that systematically used to make communication possible between people not sharing a mother tongue [1].

Standardized language at sea is very important in which agreement or convention is fundamental. The use of ME is supported by the international community and developed by the International Maritime Organization (IMO). According to Demydenko [1], ME is a System of Specialized Sub languages. Sub languages, or languages of restricted domains, are most frequently observed in technical and scientific communications. Maritime English has several sub languages: (1) General English, (2) General ME, (3) ME for Navigation, (4) ME for Marine Engineering, (5) ME for Ship's Documentation and Correspondence, 6) ME for Radio Communication, (7) Standard Marine Communication Phrase (SMCP), (8) ME for IMO Conventions, Regulations, Manuals, etc., (9) ME for Semiotic Systems, (10) ME for Visual Aids and Others. It is important to note that linguistically, Maritime English is not a separate language but just a conventional label for a subset or realization of English language appropriate to a specific maritime setting [1].

The International Convention on Standards of Training, Certification and Watch keeping for Seafarers (STCW) has stated that seafarers should have the abilities to understand orders and to communicate in English with others in relation to duties on board. It is no doubt that communication is considered as a significant aspect in the maritime field. Communication breakdown in our daily life can cause conflict and embarrassment, but communication breakdown at sea can cause much more serious effects such as damage to valuable cargoes, sea pollution, crew injury, or even death. Realizing that the crew's English competency is highly linked to the safety at sea, many shipping companies require seafarers to have good English competence and adequate knowledge of Maritime terminologies. Therefore, English proficiency becomes the major qualification for shipping companies to recruit seafarers for their vessels. Thus, maritime graduates are expected to show the ability to conduct effective and accurate communication. Maritime schools today are faced with the biggest challenge of developing seafarers with high standards of competence and professionalism with good English communication skills [2]. In relation to the significance of Maritime English for graduates, several maritime colleges and polytechnics in Indonesia have set a regulation of cadets taking Maritime English Test before they register for graduation. ISF Marlins English Language Test for Seafarers has been used by one of Merchant Marine Polytechnic in Indonesia as the prerequisite for graduation registration since the middle of 2018. Cadets have to reach a minimum score 70 for both Nautical Studies Program and Marine Engineering Program. 
ISF Marlins English Language Test for Seafarers is recognized as an online-based standardized test for Maritime English. The test consists of a total of 85 questions which are broken down into the following categories: listening comprehension (25 questions), grammar (30 questions), vocabulary (15 questions), different sound and pronunciation (9 questions), reading (1 question) and time and numbers (5 questions). The test is used worldwide by shipping companies to assess Maritime English competence of seafarers. Considering that the test has special characteristics and difficulties, the institution has provided a preparation class for the cadets before they take the test. The preparation class is conducted for 10 meetings in which each meeting consists of 100 minutes. The cadets are given materials related to Maritime English in a more specific way and they are also exposed to various question types related to the test. However, the result of the first batch who took the real test showed a disappointing result. From 192 cadets, only 47\% passed the test, while $53 \%$ of them were considered failed. That condition arose self-reflective questions from the institution: what actually went wrong?

\section{B. The Needs for ESP Coursebook Evaluation}

Evaluation towards education program is important in order to make judgement or decision for improvement. According to Hutchinson and Waters in [3] "evaluation is a matching process, matching needs to available solution.".ReaDickins and Germanie in [4] elaborated that evaluation is "a means by which we can gain a better understanding of what's effective, what's less effective and what appears to be no use at all". When an educational program does not achieve the expected outcomes, evaluation needs to be conducted on the aspects of the program.

In ESP context such as Maritime English, coursebooks have a significant contribution to the process of teaching and learning. According to Ghalandari and Talebinejad [5], materials in ESP classroom play a crucial role in exposing learners to language. For most teachers, coursebooks provide the foundation for the content of the lessons, the required skills to be taught, and the language practices that students conduct during class activities. Coursebooks are probably the best option among other sources of materials for teachers as guidance of teaching during the course.

Ellis in [6] differentiated between two types of material evaluation: predictive evaluation and retrospective evaluation. The former refers to making a decision based on the objectives for which the materials are going to be used, while the latter involves further evaluation of the materials to know whether they have worked well for the determined purposes.

Several researchers have been conducted evaluations on ESP textbooks or teaching materials. Nezhad, Atarodi, and Khalili evaluated Mechanical Engineering textbooks used in Iran. They used a checklist developed by Miekley (2005) to evaluate two textbooks published by SAMT and OXFORD. They found that the OXFORD textbook is better in terms of physical appearance and the wide range of activities provided. While the SAMT textbook excels in providing authentic materials for learning. They also found that vocabulary and grammar do not receive too much attention in both books [7].

Sarem, Hamidi, and Mahmoudie conducted an evaluation on a coursebook of English for International Tourism. Different from the previous researchers, they used a checklist developed by Daoud and Celce-Murcia (1979). Similar to the previous one, they employed qualitative descriptive analysis using self-report study. The result of their evaluation showed that the coursebook has excellent layout and physical appearance. The contents of the book are mainly skill-based, and the activities and exercises are mostly speaking and listening with some writing and reading exercises. The coursebook also has advantages by providing review unit, audio $\mathrm{CD}$, listening scripts and grammar glossary [8].

Other researchers Azarnoosh and Ganji evaluated ESP Management Coursebook. Similar to the two previous studies mentioned before, they also employed a qualitative descriptive analysis. It was also a self-reporting study using a checklist developed by Miekley (2005). The result of their evaluation showed that the book lacks visual materials and various activities to reinforce learners' vocabulary and grammatical knowledge. There is also no activity for practicing listening, how to pronounce words and sentences correctly. It also does not provide activities to encourage students' writing ability. They recommended that the book should be modified for improvement [4].

Another recent study was conducted by Chegeni, Kamali, and Noroozi [9]. They conducted an evaluation on General English textbook "Four Corners". Similar to Sarem, Hamidi and Mahmoudie [8], they used checklist developed by Daoud and Celce-Murcia (1979). They also employed qualitative descriptive analysis for their research. They found that the book "Four Corners" is well organized and uses authentic language. It gives opportunities for learners to practice the four skills: speaking, writing, listening and reading. Many colorful pictures make the appearance look interesting for students. The book also includes review units, audio $\mathrm{CD}$, listening script, self-study units, and grammar glossaries.

The studies conducted by previous researchers indicate that it is highly necessary to review the coursebook used in the classroom. Realizing the importance of coursebook evaluation, the researchers want to evaluate the coursebook used in the Preparation Class of Maritime English Test conducted in one of Merchant Marine Polytechnic in Indonesia. Different from the previous researches, this study will involve three different perspectives of the major elements in the education process:teachers, cadets, and graduates in order to obtain a comprehensive evaluation. The research questions guiding this study are: (1) How appropriate is the content of the book from the perspectives of teachers, cadets and graduates? (2) How appropriate are the vocabulary and structure provided by the book from the perspectives of teachers, cadets and graduates? (3) How appropriate are the exercises provided by the book from the perspectives of teachers, cadets and graduates? (4) How helpful are the illustrations provided by the book from the perspectives of teachers, cadets and graduates? (5) How good 
is the physical make-up of the book from the perspectives of teachers, cadets and graduates?

\section{METHOD}

\section{Materials}

The materials used for the evaluation purposes in this study was the coursebook of Preparation Class for Marlins English Test. The coursebook was composed by lecturers of Maritime English and compiled from several sources. There are three parts of the book: the main part which consists of instructions and exercises, and two supplement parts of grammar and pronunciation modules. The book has altogether 117 pages.

\section{A. Participants}

The participants involved in this study were: (1) 12 English teachers who taught Preparation for Marlins English Test program; (2) 111 cadets of Nautical Study and Marine Engineering Study who joined the Preparation for Marlins English Test program. They were randomly selected; (3) 14 Graduates of Semarang Merchant Marine Polytechnic who attended at least five sessions of the preparation class and had taken the real Marlins English Test.

\section{Instrument}

The authors used a questionnaire adapted from Daoud and Celce-Murcia's checklist which has been widely used for evaluating textbooks. There are five major sections of evaluation: (1) Subject matter, (2) Vocabulary and structures, (3) Exercises, (4) Illustration, and (5) Physical make up [10]. Few adjustments were made to suit the purpose of this study. One significant adjustment was providing a comment column for each section to obtain qualitative responses. For the cadets and graduates, the questionnaire was written in Bahasa Indonesia and for the teachers, the questionnaire was written in English (See appendix).

\section{Data Collection and Analysis}

The questionnaires for the English teachers were distributed using Google form and the teachers were asked to complete the questionnaire in not more than three days. Google form was also used for the graduates since they did not study at the campus anymore. Actually, there were 30 graduates that were given the questionnaires, but only 14 of them who completed and submitted the questionnaires back. For the cadets, the questionnaires were printed on papers. Initially, there were 125 questionnaires distributed for cadets, but only 111 of them were completed and thus could be analyzed.

The results of the questionnaires were then recapitulated and described. In this study, the authors used qualitative descriptive analysis with simple descriptive statistics.

\section{FINDINGS AND DISCUSSION}

\section{Subject Matter}

The subject matter deals with the topics and materials presented in the book, including the variation of topics, the organization of the materials, whether the materials are up- to-date and interesting for cadets or not, and whether the materials cover an appropriate balance of the four language skills or not. In this first aspect, the teachers gave the most contribution of evaluation. Majority of them agreed that the book covered various up-to-date topics and materials which were needed by cadets to complete the Maritime English Test. However, there were several things that needed improvement, especially the organization of the materials. For ten meetings of the course, there were too many materials included in the book with a lack of variation in the activity. The book also did not provide an appropriate balance of the four language skills: reading, listening, speaking and writing. It was probably because the book was designed for a test preparation which did not assess speaking ability.

The graduates and cadets had similar perspectives towards the subject matter of the book. They did not complain about this aspect. However, fifteen percent of them perceived that the materials of the textbook were less interesting, less challenging and less motivating for them due to the lack of variation.

In designing a coursebook, the subject matter should be organized carefully. A coursebook can become guidance for both teachers and learners through the course as long as it is designed and organized well. In the case of ESP materials, it is important that the materials included in the book are suitable with the learners' needs, learning objectives of the course and methodology [6]. A textbook can be a teacher, a map, a resource, a trainer and an authority. As a teacher, the book gives students relevant information about the materials. As a map, it shows an outline of the materials which guides students and teachers during the course. As a resource, the book provides materials and activities for teachers and students. As a trainer, the book can give valuable instruction and guidance for novice teachers [11].

\section{B. Vocabulary and Structures}

This aspect deals with how the book provides and presents vocabulary and grammar section, including the variation, the organization, and the suitability for cadets. All teachers agreed that the book provided systematic organization for grammar from the simple to more complicated one. The grammar section also contained examples and simple explanation that helped students to understand the materials. The book also provided a various maritime vocabulary that cadets needed. However, $59 \%$ of the teachers perceived that the vocabulary was not presented systematically. Some of them suggested that there should be vocabulary building activity included in the book and to add lists of glossaries at the end of each unit. Another weakness of the book according to the teacher was that the grammar and the vocabulary were not reviewed in the next chapter as reinforcement. The teachers perceived that cadets need drills and repetitions in learning because they could forget things easily. Based on teachers' observation, some cadets also did not have sufficient knowledge of grammatical structure. Thus, the grammar section should receive more attention.

This is in line with the perception of the graduates, that it was necessary to review vocabulary and grammar in the next 
chapter of the book. However, in general, the graduates and the cadets were happy with the vocabulary and the grammar section. Only twelve percent of cadets who perceived that the language used in the book was rather difficult. This might be caused by the low English proficiency of the cadets themselves that hinder their understanding of the materials. However, this argument needs further investigation for verification.

In ESP like Maritime English, vocabulary aspect needs to be organized carefully. Maritime English contains abundant of maritime vocabulary that has to be learned by cadets. Vocabulary in Maritime English is related to the standard words and phrases used by all seafarers around the world. Structure or grammar is also important as a tool which enables seafarers to construct sentences using vocabularies that they have learned. Combination of accurate vocabulary and correct grammar will contribute to the safety of communication at sea. Quoting Viskota and Kalibota, "increasing efforts at teaching Maritime English at maritime colleges and universities worldwide has contributed to preventing maritime accidents" [12].

\section{Exercises}

This aspect includes sufficiency and variation of the exercise and whether it can help cadets to understand the materials. The exercise of the book had been made in line with the real Maritime English test to make cadets familiar with the types of questions. There were listening activities, filling gaps, image multiple choice, making sentences using jumbled words, labelling pictures, word categorization, choosing the odd word, time and number, choosing a word with a different sound, and reading.

Majority of teachers agreed that the exercises could help cadets to obtain a better understanding of the materials. There were varieties in the exercise format, so cadets could practice various type of exercises. However, some teachers argued that the exercise of making sentences using jumbled words needed more attention. Based on their experience, cadets had more difficulty in doing this kind of exercise compared to the other kind. Therefore, it is necessary to add more exercises and examples.

The graduates and cadets perceived no significant problem with the exercises. They agreed that in general the exercises provided by the book were sufficient. The exercises also enable cadets to understand the materials more easily.

Exercise is important in a coursebook to check cadets' understanding after they are taught certain materials. It can also serve as a tool for cadets to practice their ability. It is necessary to arrange exercises, assignments, and activities in the coursebook appropriately. Repetition is essential in learning vocabulary and grammar because knowledge and understanding might not be internalized just in one meeting. Repetition can enhance the quality of knowledge and also the strength of it [13].

\section{Illustration}

The illustrations in the book were intended to help cadets to understand the materials. From the perspective of teachers, the illustrations were helpful for them and for the cadets. Teachers could use the book illustration to explain the materials to the cadets so that they can understand the materials easily. The teachers agreed that the illustrations in the book were simple, clear and not confusing. The illustrations were also interesting because they consisted of colourful pictures and diagram.

Graduates and cadets were also happy with the illustration in the book. However, some of them complained that some of the pictures were not clear due to poor picture resolution. Therefore, it is necessary to select good quality pictures to be included in the book. Despite the problem with picture resolution found in some pictures, both graduates and cadets agreed that the illustrations were interesting and helpful for them in understanding the materials.

Pictures, diagrams, or charts are great tools to enhance the process of teaching and learning. They can help teachers to deliver educational content more effectively. They can be used to reinforce the material being studied. It can increase cadets' interest in learning and makes the learning process more enjoyable [14].

\section{E. Physical Make-up}

The last section on the questionnaire used in this study is the physical make-up. It is related to the attractiveness of the book appearance. It also deals with the durability of the cover and the paper used, the font size, and the printing quality. In general, the teachers agreed that the book had a good physical make-up. The font size and the printing quality were excellent, and nothing needs to be concerned related to those aspects. They also perceived that the cover was quite attractive. However, several improvements need to be made on the supplement books. They suggest that the main coursebook and the supplement books of grammar and pronunciation should be put together, instead of making them as separate books.

Graduates and cadets had the same perception towards the physical make-up of the book. They agreed that in general, the book had good physical make-up: the font size was proportional, and the printing quality was good. However, some of them said that the cover of the book was not interesting. It seemed that the cover of the book needs to be redesigned to make it more attractive to cadets.

In this context, the jargon 'don't judge a book by its cover' [15] seemed not appropriate. In fact, the cover of the coursebook influenced cadets' interest in learning. People make the first judgement from the appearance and the first impression is highly influential for the later perception and attitude.

\section{CONCLUSION}

The process of English Language Teaching and Learning involves many elements that interconnected each other. Textbook or course book is considered as one of the important elements because it can be the source of learning for students and guidance of teaching for teachers. Even though high attempts have been made in arranging textbooks, still there are no perfect books made for the first time. In this 
case, evaluation becomes an essential part of education and cannot be separated from the process of teaching and learning itself.

This study was aimed to evaluate a course book used for Maritime English Test Preparation Class from three perspectives: teachers, cadets, and graduates. This study employed a qualitative descriptive analysis in which the researcher adapted evaluation checklist developed by Daoud and Celce-Murcia [10]. There were five aspects to be analyzed, including subject matter, vocabulary and structure, exercise, illustration, and physical make-up.

The findings of the study showed that in terms of subject matter, the organization of the materials needs to be revised. There were too many materials for a ten-meeting course, and it caused difficulties for teachers when delivering the materials. In terms of vocabulary and structure, the book provided a systematic organization for grammar including examples and explanation. The book also provided various maritime vocabulary but unfortunately, it was not presented systematically. Thus, it is suggested to add vocabulary building activity and glossary at the end of every unit to make it more systematic. The exercise part was important because it could be used to check cadets' understanding. It could also make cadets familiar with the type of questions in the real test. The book provided a sufficient number of exercises with various activities. However, the exercise of making sentences using jumbled words needs to be added in number because cadets' face difficulty when doing this kind of exercise compared to other kinds of exercises. The illustration was important to enhance the process of language teaching and learning. Cadets also found it helpful in understanding the materials even though some of the pictures were not clear due to poor resolution. In the aspect of physical make-up, the font size and the printing quality were good, but the cover needed to be redesigned to make it more attractive for cadets.

Finally, the findings of the present studies have significant implications for materials development, especially in Maritime English. In designing a coursebook, teachers and material developers need to consider several aspects. Subject matter should cover various topics or materials that are needed by cadets and should be in line with the course objectives. The materials should be organized systematically according to topics and level of difficulty. In ESP especially in Maritime English course, the vocabulary and grammar should be presented in a systematic way and provided with sufficient exercises. The illustration and physical make-up of the book should be prepared and designed well because it can enhance cadets' interest and motivation in learning.

\section{REFERENCES}

[1] Demydenko, Nadiya., "Teaching Maritime English: A Lingustic Approach" in Journal of Shipping and Ocean Engineering," 2, 249-254, 2012.

[2] Navarro, Jomarie D., Garbin, Zenaida Z., Agena, Edwin M, Gracia Olympo B,. "Maritime Students' English Proficiency and Their Feedback in Instructional Materials" in Asia Pacific Journal of Maritime Education, 1 (1), 63-81, 2015.

[3] Azarnoosh, Maryam., Zeerathpishe, Mitra., and Faravani, Akram., Issues in Coursebook Evaluation, Boston: Brill Sense, 2018.

[4] Azarnoosh, Maryam., Ganji, Maryam., "ESP Book Evaluation: The Case of Management Coursebook" in International Journal of Secondary Education, 2 (4), 61-65, 2014.

[5] Ghalandari, Shiva., Talebinejad, M. Raza., "Medical ESP Textbook Evaluation in Shiraz Medical College" in Education Research Journal, 2, 20-29, 2012.

[6] Karimnia, Amin., Jafari, Fatemeh Mohammad., "Critical Textbook Evaluation: The Case of Visual Arts Textbook" in Sustainable Multilingualism, 2, 219-236, 2017.

[7] Nezhad, Hadi Yaghoubi., Atarodi, Isa., Khalili, Maryam., "A Checklist-Based Evaluative and Comparative Study of ESP Books: The Case of Mechanical Engineering" in Journal of Foreign Language Teaching and Translation Studies, 2 (2), 5069, 2013.

[8] Sarem, Saeid Najafi., Hamidi, Hadi., Mahmoudie, Rezyan., "A Critical Look at Textbook Evaluation: A Case Study of Evaluating an ESP Course-Book: English for International Tourism" in International Research Journal of Applied and Basic Sciences, 4 (2), 372-380, 2013.

[9] Chegeni, Nastaran., Kamali, Bahrooz., Noroozi, Atousa., "General English Textbook Evaluation: A Closer Look at 'Four Corners"' in Theory and Practice in Language Studies, 6 (12), 2325-2330, 2016.

[10] Daoud, A., Celce-Murcia, M., "Selecting and Evaluating A Textbook" in M. Celce-Murcia and L. McIntosh (Eds.) Teaching English as A Second or Foreign Language, 302-307, Cambridge, MA: Newbury House Publisher, 1979.

[11] Bojanic, Radic Biljana B., Topaloy, Jagoda P., "Textbook in the EFL Classroom: Defining, Assessing, and Analyzing" in Collection of Papers of The Faculty of Philosophy, 3, 137-153, 2016.

[12] Viskota, Adelija Culic., Kalebota, Sara., Maritime English What Does It Communicate? in Transaction on Maritime Science, 2, 109-114, 2013.

[13] Nation, I.S.P., Learning Vocabulary in Another Language, Victoria University of Wellington: English Language Institute, 1999.

[14] Philominraj, Andrew., Jeyabalan, David., Vidal-Silva, Cristian., "Visual Learning: A Learner Centered Approach to Enhance English Language Teaching" in English Language Teaching, 10 (3), 54-62, 2017.

[15] Adam, Tess, Judging A Book by Its Cover: Are First Impression Acccurate?, Undergraduate Honors Theses University of Colorado, Boulder, 2012. 